Article

\title{
Increasing University Competitiveness through Assessment of Green Content in Curriculum and Eco-Labeling in Higher Education
}

\author{
Andrea Okanovićc ${ }^{1, *}$, Jelena Ješić ${ }^{2}$, Vladimir Đaković ${ }^{1}$, Simonida Vukadinović $^{2}$ and Andrea Andrejević Panić ${ }^{2}$ \\ 1 Faculty of Technical Sciences, University of Novi Sad, 21000 Novi Sad, Serbia; v_djakovic@uns.ac.rs \\ 2 Faculty of Business Economics, University Educons, 21208 Sremska Kamenica, Serbia; \\ jelena.jessic@educons.edu.rs (J.J.); simonida.vukadinovic@educons.edu.rs (S.V.); \\ andrea.andrejevic@educons.edu.rs (A.A.P.) \\ * Correspondence: andrea.katic@uns.ac.rs; Tel.: +381-63-848-36-38
}

check for updates

Citation: Okanović, A.; Ješić, J.; Đaković, V.; Vukadinović, S.;

Andrejević Panić, A. Increasing University Competitiveness through Assessment of Green Content in Curriculum and Eco-Labeling in Higher Education. Sustainability 2021, 13, 712. https://doi.org/10.3390/ su13020712

Received: 1 December 2020 Accepted: 6 January 2021 Published: 13 January 2021

Publisher's Note: MDPI stays neutral with regard to jurisdictional clai$\mathrm{ms}$ in published maps and institutional affiliations.

Copyright: () 2021 by the authors. Licensee MDPI, Basel, Switzerland. This article is an open access article distributed under the terms and conditions of the Creative Commons Attribution (CC BY) license (https:// creativecommons.org/licenses/by/ $4.0 /)$.

\begin{abstract}
Growing environmental problems and increasing requirements of green jobs force universities around the world not only to transform their curricula but also to enrich existing ones with contents related to the promotion of sustainable development. This paper aims to show the importance of measuring and monitoring the share of green contents in all university activities, as only in that way it is possible to monitor trends and give realistic assessments of their effect and importance. The paper presents a comparative analysis of different types of methodologies for assessing sustainable activities at universities as well as research conducted at the University of Novi Sad in Serbia and its comparison with the University of Gothenburg (Sweden). This research aims to point out the importance of increasing competitiveness in higher education through assessment of green content in a curriculum and its promotion. In this way, through eco-labeling methodology, it would be easier to identify those contents that, in a certain share, contribute to the promotion of sustainable development. Furthermore, this methodology can easily be extended across the country and the region, which would bring positive effects to all stakeholders in higher education.
\end{abstract}

Keywords: sustainable development; green campuses; green study programs; sustainability management tools; green eco-labels

\section{Introduction}

In response to a series of global environmental crises that occurred at the end of the last century, in recent decades, there has been increased public concern about the negative impact of human activities on the condition of the environment. According to the report of the World Commission on Environment and Development (WCED), better known as the 1987 Brundtland Report, sustainable development can be defined as "the development that meets the needs of present generations without compromising the ability of future generations to meet their needs" [1]. During this period, the topic related to sustainability and sustainable development became popular and discussed a lot in scientific and political circles. Although the initial success was limited, the mentioned topics were included in a large number of national and global policies [2]. Today, many actors are engaging in the fight to accomplish the so-called Sustainable Development Goals (SDGs) or Global Goals set under the 2030 Agenda for Sustainable Development to eradicate poverty in every sense on the whole planet [3]. For this reason, companies and other organizations are placed in a position to take into account the roles of environmental issues in economic effects [4]. The World Economic Forum (WEF) focused on the study of sustainable competitiveness, which once again emphasized the need to monitor sustainable development factors in order to achieve greater competitiveness.

The importance of including the higher education (HE) sector, in the fight for a healthier environment, was recognized as early as in 1992 through Agenda 21, which 
emphasizes the need for Education for Sustainable Development (ESD). Namely, several studies have proven the link between appropriate learning about sustainable development and responsible student behavior as an impact indicator [5]. Thus, for example, according to [6], ESD leads to a change in behavior of people that results in 10-20\% savings in energy consumption. The goal of this view of education is to connect ecological, economic, and environmental aspects in the teaching process [7]. For this reason, universities have an obligation to include more content dedicated to sustainable development in their study programs, which, at the same time, promotes the importance of environmental behavior in the wider society [8]. Aware of their role in society, universities around the globe seek to make green their programs and courses and thus contribute to achieving global goals in the field of sustainable development [9]. In this way, the education system will enable people to take more care and responsibility for the environment and thus provide coming generations with a sustainable future. The authors of [10] define a green curriculum as the curriculum that is "taking environmental protection, natural conservation, resources saving and rational utilization, and advocacy of environmental friendliness as the principal content and teaching objectives".

In addition to including green contents in teaching, universities also strive to demonstrate their commitment to preserving the environment in a practical way by building sustainable campuses. This academic community activity implies the active role of teaching staff, students, and university partners who have great potential to enable themselves and others to live in a healthier environment, and some of the useful methods to encourage them are the assessment of green content in a curriculum and use of eco-labels.

The subject of the research is the assessment of green contents in the teaching curriculum of academic study programs, bachelor and master, at the University of Novi Sad (Serbia). The research also includes a comparison of different assessment organizations and their methods, with a special emphasis on curriculum. The research objective is to determine the importance of measuring and monitoring the share of green contents in all university activities, with a special emphasis on the eco-labeling of study programs as a tool for promoting good practice. The hypothesis of the paper is the following: Assessment of green content in a curriculum is essential to achieve sustainable competitiveness of university campuses. The motivation of the research is to enable the creation of scientifically verified and pragmatic bases of university competitiveness through green assessment of study programs, which has wider importance for the socio-economic community. The research is important for both the academic community and professionals, with a special emphasis on policymakers in the subject field.

The paper consists of the following sections. Section 1 lists the basic assumptions of the subject matter with an explanation of the subject, goal, and main hypothesis of the research. Section 2 determines conceptual research problems with an exemplary introspection of successful practices. Section 3 describes the research context and method for assessment of green content of study programs in higher education. Section 4 presents a discussion of the research results, and Section 5 gives concluding remarks and directions for further research, as well as the list of used literature.

\section{Conceptual Problems}

\subsection{Sustainable Competitiveness}

For a long time, gross domestic product (GDP) per capita and the level of productivity were considered the main indicators of success at the macro and micro levels, respectively. However, later, many studies such as [11] have shown that competitiveness is not the result of individual factors but that, on the contrary, it depends on a multitude of relations and numerous indicators. According to the definition of the European Commission, "an economy is competitive if its population can enjoy a high and rising standard of living, as well as a high-level sustainable employment" [12]. At the micro-level, one of the popular definitions of competitiveness says that this term represents: "the firm's ability to sustainably fulfill its dual role: fulfilling customer requirements and earning profits" [13]. 
Today, we can see that measuring competitiveness has become a science in itself, attracting numerous researchers to deal with it. For this reason, the last decade has seen a sharp increase in the number of different models and approaches to measuring competitiveness, which, in turn, has led to specialized trends as well as to the research on a large number of indicators on which competitiveness at different levels could depend [14].

The third and fourth industrial revolutions brought about new changes that greatly affected the environment and led to a lack of available resources and shaky ecosystems [15]. One of the leading international institutions, the World Economic Forum, defined sustainable competitiveness as: "the set of institutions, policies, and factors that make a nation productive over the longer term while ensuring social and environmental sustainability" [16]. In fact, only through the integration of multiple perspectives-economic, social, and environmental—can sustainable competitiveness be understood $[17,18]$. The whole concept, in short, can be presented as: "the ability to meet the economic, social and environmental needs of society" [19]. Thus, it is essential to observe and promote university green entrepreneurial support of students' green entrepreneurial intentions by formulating and implementing strategy directions with both economic and non-economic multiple gains for the broader social-economic community, especially investors, entrepreneurs, students, and universities as the core. Their sustainability, green content, and also the significance of the establishment of sustainable ecosystems are further emphasized [20-22].

Such changes were a signal to scientists dealing with competitiveness to include new indicators into their research that show progress towards a green economy based on sustainable development $[23,24]$. Indicators describing sustainable development were first included in many models that measure general competitiveness such as the Global Competitiveness Index, the Europe 2020 Strategy Competitiveness Index, the Global Innovation Index, etc. [25]. In recent years, as the importance of this topic increases, a large number of models specialized to precisely measure sustainable competitiveness at different levels have been developed. Examples of such models include the Global Sustainable Competitiveness Index, the Global Destination Sustainability Index, Sustainable Economic Welfare, the Sustainable Cities Index, the Climate Change Performance Index, the Global Green Economy Index, the Environmental Sustainability Index, the Environmental Performance Index, etc. It can be concluded that the issue of measuring the achieved level of sustainable competitiveness is very attractive for today's scientists, as well as the fact that there is no single model that best reflects the achieved level in this field, as evidenced by numerous studies [26].

\subsection{The Importance of Making Study Programs Green}

Nowadays, the higher education sector has been facing the effects of several new factors arising as a result of high technology development under the fourth technological revolution. Special challenges for university centers are the development of artificial intelligence, robotics, autonomous vehicles, augmented reality and virtual reality technology, and also the mass access of students to numerous smart devices with a high-speed internet connection [27]. There have also been changes in terms of students' mobility, who increasingly prefer green modes of transport such as electric scooters. Namely, with their influence, universities are trying to promote sustainable modes of transport, which has an effect not only on the environment and the economy but also on student education [28]. Furthermore, the interests of today's students are increasingly focused on solving problems and topics such as mitigating climate change effects and saving energy and other resources as well as proper waste disposal. Along with the strengthening of the environmental awareness of university students and teaching staff, various concepts and methods have been used in teaching that promote environmental protection. Namely, it is considered that sustainable development is one of the key drivers of upcoming technological changes as people are becoming more aware of the negative consequences of their actions on the environment [29]. 
In the paper [30], it was argued that the development of green study programs is essential regarding the establishment of a progressive green university using a maturity assessment tool and framework in the function of achieving and maintaining a competitive advantage, which is especially important in dynamic business conditions. Researchers [31] investigated the current state and conditions of environmental management with special attention to universities and the possibility of making the study programs green. Their work is significant because it stressed the necessity of participatory methods of governance, having in mind more sustainable and green best practices in universities.

Today's students, especially future engineers, must have the necessary knowledge that would allow them to balance the social, economic, and environmental aspects of the industrial activities in which they are involved [32-34]. For this reason, universities around the world, especially in the last fifteen years, have been implementing content dedicated to sustainable development in their programs [35]. In their research, the authors of [36] presented examples of good practice of including the concepts of sustainable development in programs at seven different universities from seven different countries. Some of the conclusions they came to refer to the need to help students develop critical thinking and change their own values in terms of sustainable development; providing students with insight into projects and examples of good practice in the form of case studies, as well as bringing lecturers from the field of economy [36]. The literature also offers numerous proposals related to the way of integrating sustainable development into the curriculum. Some authors even suggest involving students in the creation of teaching contents and curricula, as in that way, they would feel more related to the postulates of sustainable development. In that case, students could propose, criticize, and provide solutions related to the introduction of the concepts of sustainable development in study programs [37]. Models that include the introduction of case studies, creative problem solving, and understanding different aspects of a problem are also proposed [38]. The results in [38] show that engineering students perform problem analysis and case studies through six levels of Bloom's taxonomy, which include knowledge, comprehension, application, analysis, synthesis, and evaluation with increasing skill.

On the other hand, some solutions indicate the need to connect broader structures in the promotion of sustainable development and that we should talk about the establishment of so-called sustainable university campuses [39]. Some authors actually consider making the campus green as the first step towards achieving an appropriate degree of university sustainability [40]. Furthermore, some authors believe that it is not enough to provide students with appropriate theoretical knowledge about the principles of sustainable development and that they also need an appropriate environment in which they could implement the learned principles in practice during the study period [41]. Sustainable campuses are considered places that provide students with all the necessary conditions in which they can learn and practically apply the main principles of sustainable development regardless of the study program. One of the first green initiatives at universities was the iChange competition run in 2013, held by Connect4Climate initiative, a global partnership program of the Communication for Climate Change Multi-Donor Trust Fund (MDTF) at the World Bank Group. The competition received 248 entries from students from 165 universities across 66 countries, demonstrating the power of global youth participation [42]. At Hokkaido University in Japan (2020), a sustainable university campus is defined as, "a university that contributes to building of a sustainable society through education, research, collaborating with the society and campus development" [43].

\subsection{Measuring the Success of Sustainable University Activities}

There are numerous examples of world universities that, through their activities, want to contribute to the preservation of sustainable development principles in various ways. Through their activities, universities strive to influence the improvement of the environment that surrounds us but also to improve their own corporate image through so-called green marketing. Namely, research has shown that higher education institutions 
with a positive image can count on increased student enrollment rates, increased loyalty, and increased positive word of mouth [44].

According to a study by McIntosh et al., (2008), between 2001 and 2008, the commitments made by the studied universities to promote sustainable development increased by $43 \%$ [45]. However, although the number of universities promoting sustainable development is increasing, the problem that arises concerns the lack of adequate data to measure their success [46-48]. Numerous published scientific models and organizations help universities to approach the so-called greening of their programs and campuses in the right way. Some authors also suggest the creation of a composite competitiveness index that measures the degree of sustainability of a university campus [49]. Namely, as we live in a time of fast and clear information, universities are expected to receive adequate confirmation from some relevant organizations for their green practice. For this reason, entities and associations have been established that deal with data collection, model formation, and ranking of the best practices in the field of green universities. In order to better understand the existing models, the paper performs a comparative analysis of different models that show the assessment of sustainable activities at the university.

\subsection{Eco-Labels (Origin, Development, and Significance)}

Today's consumers are paying more and more attention to the impact of products and services on human health and the environment, at all stages of their life cycle. For this reason, many companies choose to use some of green marketing tools such as eco-labels, promotion of eco-products, as well as investing certain resources in improving environmental protection and sustainable development. Research shows that a company will have better results if it integrates eco-labeling strategies and a green marketing mix into the decision-making process [50]. In this way, consumers receive more complete information when it comes to the impact of their decision to purchase a particular product or service on ecology and sustainable development [51-53]. Some authors even believe that this way of labeling also allows consumers to learn more about the method of production/service provision and disposal of products after use [54]. Because of all of the above, eco-labels are considered a useful tool for achieving greater sustainability of consumption, especially when it comes to products or services of which the use may have a negative impact on the environment [55]. In this way, eco-labels provide customers with a choice that contributes to improving the environment as well as accomplishing the goals of national, regional, and global strategies (e.g., reducing $\mathrm{CO}_{2}$ in the air, improving energy efficiency, etc.) [56].

We may single out eco-labeling in service activities as a special category of eco-labels, which includes higher education [57]. However, there are a small number of papers in the literature dedicated to this topic, which makes it very challenging to research. From the existing studies, we can single out the research by Hickman and Meyer (2016) which is focused on the efficiency of eco-labeling in higher education. The study analyzed the impact of the signing of the American College and University Presidents' Climate Commitment by higher education institutions on student enrollment. The results showed a very positive correlation, meaning that the institutions that signed this charter subsequently faced increased enrollment rates and student interest [58]. Furthermore, a very positive example of the application of eco-labels in study programs was given by the University of Gothenburg, which will be presented in the paper in a later section.

\section{Research Context, Method, and Results}

\subsection{Research Context}

With the literature review, the authors found few studies that deal with the analysis of existing models for the assessment of sustainable activities in universities. In the following text, the best models, their advantages and disadvantages will be singled out, with a special analysis of the green content in the curriculum. Also, in this part of the paper, an example of evaluation of green content in programs at faculties that are members of the University of Novi Sad in Serbia is presented. 


\subsubsection{Assessment and Sustainability Management Tools for Universities}

Research [40] shows an overview of campus sustainability assessments tools as well as the frequency of indicators related to physical elements such as energy, air and climate, buildings, soil and ecosystem, transportation, waste, water, food and recycling. Furthermore, it is interesting to point out the study [59], whose authors analyzed nine models for assessing the sustainability of higher education institutions using the criteria developed by the Global Reporting Initiative and the Association of University Leaders for a Sustainable Future. The results of the study show that the Pacific Sustainability Index and the Sustainability Tracking and Assessment Rating System (STARS) have the most comprehensive assessment tools in this sector [59]. It is also important to describe several other sustainability management tools important for higher education which do not include the assessment of the curriculum itself. For example, the model called "The Times Higher Education Impact Rankings", which analyzes more than 1500 universities across 93 countries and evaluates universities against the United Nations' SDGs. Its indicators provide balanced comparisons across four areas: teaching, research, knowledge transfer, and international outlook. The metrics were developed in partnership with Vertigo Ventures [60]. Another example is the International University Sports Federation (FISU) Healthy Campus program which includes 35 universities from 24 countries. With the Healthy Campus program, universities embed concrete health and wellness resources into all aspects of campus life and culture. Colleges receive Healthy Campus Certified status based on 100 criteria developed by leading global experts. Universities are evaluated across seven domains: Physical Activity and Sport; Nutrition; Disease Prevention; Mental and Social Health; Risk Behavior; Environment, Sustainability, and Social Responsibility; and Management of Healthy Campus [61].

In addition to models aimed directly at measuring sustainable university activities, it is worth mentioning those that are broader set but can be adapted to the needs of the higher education sector. Such is the case, for example, with the SDG Action Manager tool (developed by the UN Global Compact in collaboration with B Lab, which gives companies the opportunity to set clear goals on the SDGs and benchmark progress against standards) [62]. On the other hand, some models are focused on certain professions such as an organization called "The Principles for Responsible Management Education (PRME)", which is a United Nations-supported initiative founded in 2007. PRME brings together business and management schools in order to provide them with the appropriate skills needed to balance economic and sustainability goals, with a special focus on Sustainable Development Goals (SDGs). In this way, this organization makes a connection between the United Nations and management-related higher education institutions [63]. Furthermore, a large number of models have been developed aimed at a lower level of education, such as initiative "Eco-Schools" which have been developed by a European educational program. Today, it is the largest global sustainable schools program and model for environmental education and sustainability at the international level (with national coordination and recognition and awards) [64].

While from the literature, $[40,65]$ show representations of models with their advantages and disadvantages, this paper presents a more comprehensive analysis with a particularly prominent assessment of the curriculum. The first part of the research is dedicated to comparing different types of methodologies for assessing sustainable activities at universities. The study includes seven different organizations from different countries. The paper shows an overview and assessment of the best methodologies of organizations that support the establishment of sustainable university campuses. Table 1 shows a comparative analysis of all the described assessment organizations based on several categories. The research includes an assessment of the advantages and disadvantages of each of the described methodologies. The tool for assessing sustainable content in the university curriculum was analyzed in particular. The used methodology, assessment categories, and objective of the framework are analyzed as well. 
Table 1. Assessment and sustainability management tools for universities.

\begin{tabular}{|c|c|c|c|c|c|c|}
\hline Organization Name & Methodology & Assessment Categories & Objective & $\begin{array}{l}\text { Assessment of Green } \\
\text { Content in Curriculum }\end{array}$ & Advantages & Disadvantages \\
\hline $\begin{array}{l}\text { Sustainable Campus } \\
\text { Network (Chile) }\end{array}$ & $\begin{array}{l}\text { Adaptable model for } \\
\text { assessing sustainability } \\
\text { (AMAS) methodology for } \\
\text { sustainability assessment in } \\
\text { HE, hierarchical method of } \\
\text { analysis, construction of } \\
\text { composite index [66] }\end{array}$ & $\begin{array}{l}\text { Management and } \\
\text { supervision; Sustainable } \\
\text { culture; University } \\
\text { activities; Campus } \\
\text { management; } \\
\text { Social responsibility }\end{array}$ & $\begin{array}{l}\text { Calculating the degree } \\
\text { of application of } \\
\text { sustainability in } \\
\text { higher education } \\
\text { institutions }\end{array}$ & $\begin{array}{l}\text { Curriculum assessment } \\
\text { at undergraduate } \\
\text { studies; Curriculum } \\
\text { assessment at higher } \\
\text { levels of studies }\end{array}$ & $\begin{array}{l}\text { Easy information } \\
\text { gathering, fast results, } \\
\text { easy comparison }\end{array}$ & $\begin{array}{l}\text { Possible manipulation of } \\
\text { input indicators in } \\
\text { measuring and } \\
\text { obtaining unrealistic } \\
\text { rankings; absence of } \\
\text { measuring sustainable } \\
\text { content in the } \\
\text { curriculum }\end{array}$ \\
\hline $\begin{array}{c}\text { International } \\
\text { Sustainable Campus } \\
\text { Network (Worldwide) }\end{array}$ & $\begin{array}{l}\text { Case studies, project } \\
\text { approach [67] }\end{array}$ & $\begin{array}{l}\text { The Sustainable } \\
\text { Development } \\
\text { Goals (SDGs) }\end{array}$ & $\begin{array}{l}\text { Promoting examples } \\
\text { of good practice of the } \\
\text { concept of sustainable } \\
\text { development at } \\
\text { universities }\end{array}$ & $\begin{array}{l}\text { Improving the } \\
\text { curriculum by } \\
\text { introducing content of } \\
\text { SD within the } \\
\text { goal-quality education }\end{array}$ & $\begin{array}{l}\text { Indicators are not } \\
\text { strictly defined; there } \\
\text { is a possibility to } \\
\text { adjust the activities of } \\
\text { the university within } \\
\text { the goals }\end{array}$ & $\begin{array}{l}\text { Impossibility of } \\
\text { adequate comparison } \\
\text { and ranking of } \\
\text { universities }\end{array}$ \\
\hline $\begin{array}{l}\text { The Sustainability } \\
\text { Tracking, Assessment } \\
\text { and Rating System } \\
\text { (Worldwide, mostly } \\
\text { North America) }\end{array}$ & Collecting points [69] & $\begin{array}{l}\text { Academics; Engagement; } \\
\text { Operations; Planning and } \\
\text { administration; Innovation } \\
\text { and leadership }\end{array}$ & $\begin{array}{l}\text { Calculating the degree } \\
\text { of application of } \\
\text { sustainability in HE } \\
\text { institutions }\end{array}$ & $\begin{array}{l}\text { Curriculum assessment } \\
\text { at undergraduate } \\
\text { studies; Curriculum } \\
\text { assessment at higher } \\
\text { levels of studies } \\
\text { (number and percentage } \\
\text { of programs, number } \\
\text { and percentage of } \\
\text { students) }\end{array}$ & $\begin{array}{l}\text { Easy information } \\
\text { gathering, fast results, } \\
\text { easy comparison }\end{array}$ & $\begin{array}{l}\text { Possible manipulation of } \\
\text { input indicators in } \\
\text { measuring and } \\
\text { obtaining unrealistic } \\
\text { rankings }\end{array}$ \\
\hline $\begin{array}{l}\text { The ProSPER.Net } \\
\text { alliance (Asia-Pacific) }\end{array}$ & $\begin{array}{l}\text { Project approach of } \\
\text { reporting, based on } \\
\text { proposed objectives, } \\
\text { strategies, actions, and } \\
\text { deadlines [72] }\end{array}$ & $\begin{array}{l}\text { Curriculum reform;Strong } \\
\text { education and research } \\
\text { programs; Vision; Creating } \\
\text { a sustainable society; } \\
\text { Active participation of } \\
\text { HE institutions }\end{array}$ & $\begin{array}{l}\text { Building a community } \\
\text { of HE organizations } \\
\text { whose goal is } \\
\text { transformation in the } \\
\text { direction of SD }\end{array}$ & $\begin{array}{l}\text { Realization of the project } \\
\text { called "Integrating } \\
\text { Sustainability in } \\
\text { Business Curricula" }\end{array}$ & $\begin{array}{l}\text { Indicators are not } \\
\text { strictly defined; there } \\
\text { is a possibility to } \\
\text { adjust the activities of } \\
\text { the university within } \\
\text { the goals }\end{array}$ & $\begin{array}{l}\text { Impossibility of } \\
\text { adequate comparison } \\
\text { and ranking of } \\
\text { universities }\end{array}$ \\
\hline
\end{tabular}


Table 1. Cont.

\begin{tabular}{|c|c|c|c|c|c|c|}
\hline Organization Name & Methodology & Assessment Categories & Objective & $\begin{array}{l}\text { Assessment of Green } \\
\text { Content in Curriculum }\end{array}$ & Advantages & Disadvantages \\
\hline $\begin{array}{l}\text { People and Planet's } \\
\text { University League } \\
\text { (United Kingdom) }\end{array}$ & $\begin{array}{l}\text { Hierarchical method of } \\
\text { analysis, construction of } \\
\text { composite index [73] }\end{array}$ & $\begin{array}{l}\text { Environmental policy and } \\
\text { strategy; Human } \\
\text { Resources and staff; } \\
\text { Environmental audits and } \\
\text { systems; Ethical } \\
\text { investment and banking; } \\
\text { Carbon management; } \\
\text { Workers' rights; } \\
\text { Sustainable food; Staff and } \\
\text { student; Engagement; } \\
\text { Education; Energy sources; } \\
\text { Waste and recycling; } \\
\text { Carbon reduction; } \\
\text { Water reduction }\end{array}$ & $\begin{array}{c}\text { To improve } \\
\text { sustainability in HE } \\
\text { through rewards }\end{array}$ & $\begin{array}{l}\text { Curriculum assessment; } \\
\text { training of teaching staff }\end{array}$ & $\begin{array}{l}\text { Encourage the public } \\
\text { disclosure of } \\
\text { information relevant } \\
\text { to sustainable } \\
\text { development }\end{array}$ & $\begin{array}{l}\text { Possible manipulation of } \\
\text { input indicators in } \\
\text { measuring and } \\
\text { obtaining unrealistic } \\
\text { rankings }\end{array}$ \\
\hline $\begin{array}{c}\text { The EU } \\
\text { Eco-Management and } \\
\text { Audit Scheme } \\
\text { (Europe) }\end{array}$ & $\begin{array}{l}\text { Eco-Management and Audit } \\
\text { Scheme (EMAS) } \\
\text { methodology, } \\
\text { Environmental Management } \\
\text { System (EMS) [75] }\end{array}$ & $\begin{array}{c}\text { Organizational } \\
\text { information; } \\
\text { Environmental aspects; } \\
\text { Environmental } \\
\text { responsibilities; } \\
\text { Environmental data }\end{array}$ & $\begin{array}{l}\text { Improving } \\
\text { environmental } \\
\text { performance of } \\
\text { organization }\end{array}$ & $\begin{array}{l}\text { Special indicator for } \\
\text { universities; greening } \\
\text { curricula }\end{array}$ & $\begin{array}{l}\text { A large number of } \\
\text { quantitative indicators, } \\
\text { easy calculation of the } \\
\text { composite indicator; } \\
\text { easy to use } \\
\text { management tool }\end{array}$ & $\begin{array}{c}\text { The methodology is not } \\
\text { designed specifically for } \\
\text { HE institutions }\end{array}$ \\
\hline $\begin{array}{l}\text { UI Green Metric } \\
\text { (Worldwide) }\end{array}$ & $\begin{array}{l}\text { Philosophy that } \\
\text { encompasses the three Es: } \\
\text { Environment, Economics, } \\
\text { and Equity [78] }\end{array}$ & $\begin{array}{l}\text { Setting and Infrastructure } \\
\text { (15\%); Energy and Climate } \\
\text { Change (21\%); Waste } \\
\text { (18\%); Water (10\%); } \\
\text { Transportation }(18 \%) ; \\
\text { Education and } \\
\text { Research }(18 \%)\end{array}$ & $\begin{array}{l}\text { To provide the result } \\
\text { of the current } \\
\text { condition and policies } \\
\text { related to Green } \\
\text { Campus and } \\
\text { Sustainability in } \\
\text { universities all over } \\
\text { the world }\end{array}$ & $\begin{array}{l}\text { The ratio of } \\
\text { sustainability courses } \\
\text { towards total } \\
\text { courses/subjects }\end{array}$ & $\begin{array}{l}\text { It is easy to take part; } \\
\text { the process is } \\
\text { relatively simple and } \\
\text { not much time } \\
\text { consuming }\end{array}$ & $\begin{array}{l}\text { Online survey-possible } \\
\text { manipulation of input } \\
\text { indicators in measuring } \\
\text { and obtaining unrealistic } \\
\text { rankings }\end{array}$ \\
\hline
\end{tabular}

Source: Authors. 


\section{Sustainable Campus Network (Chile)}

The Sustainable Campus Network is part of a UNESCO-funded project called The Green Citizens. The project aims to promote education for sustainable development, i.e., to motivate people around the world to show examples of good practice in how they help to enrich knowledge about ecology and environmental protection in different ways. The network consists of 15 different universities in Chile. The mission of the Sustainable Campus Network is to promote relevant teaching methods in the field of sustainable development in higher education. In order for a university to be able to access the network, it is expected to conduct an active campaign on campus to promote ecology and the principles of sustainable development using various tools. The goal of the Sustainable Campus Network is to build a society that respects the principles of environmental protection and sustainable development through the establishment of closer interaction between universities, companies, and society [66].

\section{Sustainable Campus Network (Worldwide)}

The International Sustainable Campus Network (ISCN) is a network of higher education institutions with a mission to enable its members to quickly exchange information, good practices, and ideas in the field of disseminating information on sustainable development on university campuses, as well as integrating knowledge on this topic into study program curricula. The ISCN includes over 80 universities from 30 countries that work together to better serve their environment and the communities in which they are located. The ISCN helps universities to test new ideas in practice, measure their impact, and compare them with other institutions or over time [67]. This organization has supported numerous programs and projects such as The EcoCampus NTU within Nanyang Technology University, Singapore, which launched the initiative to achieve 35\% energy, water, and waste intensity savings from 2011 to 2020. In this way, the above university aims to become one of the eco-friendliest campuses in the world [68].

\section{The Sustainability Tracking, Assessment, and Rating System (Worldwide, mostly North America)}

The Sustainability Tracking, Assessment, and Rating System (STARS) is a self-reporting and transparent system aimed at measuring the achieved results of universities in the field of sustainable development. This platform is currently used by close to 1000 universities and institutions related to them around the world. The grades the participants receive vary depending on their performance in the field of sustainable development, and they can receive a bronze, silver, gold, or platinum STAR badge or STARS Reporter award [69]. In addition, institutions are ranked according to the recognized Sustainable Campus Index, which is published and formed annually. This index ranks organizations by 17 areas of influence related to academic practice, community impact, campus activities, and leadership. An example of good practice is the University of Illinois at Chicago, which won the silver STAR badge for 2018. As the only state research university, this institution is committed to ecology in all aspects of its business strategy. In order to promote sustainable development, the university has made a plan to combat climate change, which consists of numerous ideas and solutions that it will strive to implement in the period from 2018 to 2028 [70].

\section{The ProSPER.Net Alliance (Asia-Pacific)}

The ProSPER.Net alliance was founded in 2008 to promote a sustainable economy and environmental protection in the Asia-Pacific region [71]. Many relevant institutions are members of this alliance, and its current activities are mostly focused on the promotion of sustainable development in higher education, i.e., implementation of the Global Action Program (GAP) on Education for Sustainable Development. The ProSPER.Net alliance is actively involved in the implementation of many projects that contribute to environmental improvement, and one of them is a project called the Disaster Resilience and Sustainable Development Education Network in Asia. The goal of this project is to form a strong 
regional network with activities aimed at reducing the negative impact of various spheres of society on the environment. The activities of this project also include curriculum revision to integrate sustainable development contents into postgraduate courses and curricula [72].

People and Planet's University League (United Kingdom)

The People and Planet association is a student network, the members of which are universities across the United Kingdom, with a goal of encouraging the activities of higher education in the direction of sustainable development. This association has developed its own methodology for ranking UK universities by 13 environmental and ethical factors [73]. Half of the data are collected from the websites of the universities which are expected to transparently publish and promote as much content as possible related to social responsibility and ecology, while the other half of the data are obtained from relevant statistical publications. According to the ranking list for 2019, Newcastle University was ranked 12th out of 154 universities. This university received the most points within the Carbon Management factor, as it developed its own Carbon Management Plan according to which the university is expected to have net-zero carbon dioxide emissions by 2040 . To realize this plan, the university implemented some projects in the field of research and investment in renewable energies, decarbonizing heating and cooling, heating and ventilation system upgrades, etc. [74].

The EU Eco-Management and Audit Scheme (Europe)

Environmental management systems (EMSs) are the most widely used standards in the world in the field of activating organizations around the issue of environmental protection. The EMS comprises two international standards: ISO 14001 set in 1996 by the International Organization for Standardization (ISO) and the Eco-Management and Audit Scheme (EMAS) set in 1993 by the European Commission [75]. The EU Eco-Management and Audit Scheme (EMAS) is a management system developed to enable different types of organizations to monitor, evaluate, and improve their performances in the field of environment. The main principles of the EMAS are performance, credibility, and transparency in its operation [76]. The EMAS system has great potential for successful application in higher education institutions. Universities are actually a special type of EMAS organization because they include a large number of service users, i.e., students [77].

\section{UI Green Metric (Worldwide)}

The UI Green Metric World University Ranking is an initiative launched in 2010 in Indonesia. This methodology allow ranking with quick comparisons among universities on the criteria of their commitment to addressing the problems of sustainability and environmental impact. Universities need to provide numeric data on a number of criteria which include information about the size of the university, the campus location, and the amount of green space; use of energy, transport, water use, and recycling and waste treatment. Universities are also asked about their green policies and management [78].

\subsubsection{Advantages of Using EMAS in Higher Education}

In the continuation of the research, the authors of the paper will specifically analyze the EMAS methodology due to its wide application in Europe. Although some authors [79] believe that the EMAS methodology is insufficiently suitable for universities, this tool is becoming more widespread in higher education institutions across Europe. Namely, according to data for 2020, the EMAS system is mostly used by universities in Germany (1119 registered), Italy (1004), and Spain (964) [76]. Some of the best examples of successful implementation of the EMAS system can be found at universities across Europe. Special mention should be made of the Polytechnic University of Valencia, with 30,000 students and the EMAS system registered in 2009, and the University of Gothenburg (Sweden), with nearly 40,000 students, at which EMAS system was registered in 2004 together with the ISO 14001 quality standard. Furthermore, a successful example is the Vienna University of Economics and Business (22,000 students), which, in just two years since the registration of 
the EMAS system, received the Austrian EMAS Award 2018. The University commits to the principle of sustainability within teaching, research, knowledge transfer, and university management [78].

The University of Gothenburg, included in the EMAS system, has also a developed an active Environmental Management System (EMS) which is certified under the ISO 14001 standard. The University of Gothenburg currently has about 47,500 students and about 5000 employees, which make up a strong base for achieving its mission in contributing to sustainable development [80]. Boman and Andersson (2013) presented an eco-labeling system for study programs developed at the mentioned university [57]. The idea itself originated back in 2005 when the university wanted to "green" its programs by including contents on ecology and sustainable development. To confirm the success of this campaign, the university has set up a working group to examine all the courses and check the extent to which they contain lessons related to sustainable development. Later, these activities led to the idea that course/program holders could evaluate themselves by several criteria, and based on that, the course/program was awarded an appropriate eco-label. Research conducted in 2008 that assessed student knowledge at the same university found that $14 \%$ of students knew about eco-labels for courses/programs, while $10.8 \%$ said that this system meant something to them when deciding to enroll in specific course/program [81].

\subsubsection{Case Study-University of Novi Sad, Serbia}

The current research is focused on the possibility of applying green strategies at the University of Novi Sad (UNS) in Serbia, which is one of the greatest higher education institutions in Central Europe. The UNS offers programs from almost all fields of science, and over 50,000 students and 5000 employees study and work there [82]. The University offers over 400 contemporary study programs at all levels of studies, and their holders are faculties and university centers as well. Furthermore, within the university, there are three scientific institutes, numerous libraries offering access to large electronic databases, 250 laboratories, as well as a developed student campus. A special contribution to the UNS is given by the technology park within which over 140 highly innovative start-up and spin-off companies have been established, mostly from the IT sector, where young engineers can find jobs. Thanks to its prominent work, Novi Sad has become known as the "software valley" in international circles [82].

Due to all of the above, the UNS is an ideal environment for the implementation of green strategies modeled after many European and international universities. Namely, the UNS has certain elemental policies aimed at promoting sustainable development. Namely, in its statute, the UNS emphasizes that all of its higher education units have the obligation to take care of environmental protection as well as to develop the green awareness of employees and students through teaching processes, scientific and research work, and popularization of ecology [83]. Furthermore, the UNS has a separate Center for Sustainable Development and Environment, tasked to help educate staff in the field of environmental protection and ecology. However, the UNS does not have a clear development strategy to follow and reflect on its members, that is, individual faculties [83].

\subsection{Assessment Methodology}

From the review of the literature aimed at measuring the success of university center activities by the criterion of sustainability, it follows that curriculum evaluation is one of the basic starting points for adopting green strategies at the university [9]. For that reason, the research will be focused on measuring the share of sustainable-development-related content in the curricula of individual universities. The research was focused on determining the green content at the University of Novi Sad (Serbia), based on the guidelines of the EMAS methodology. All collected data were obtained from official institutions' sites in 2020 and the data were statistically processed. In order to target green content in the curriculum, the authors used a method of linking with key words such as "sustainable development", "ecology", "recycling", "environmental protection", "pollution reduction", etc.; a similar 
procedure was used in the paper [10]. We used the program greening index (PGI) [10] for calculating share of green content in each faculty program. The one-way ANOVA test was used for testing the data and observing whether there are significant differences in the context of "green content" in the bachelor's and master's studies at the University of Novi Sad. Following the example of [57], the programs were evaluated and categorized by the defined criteria (Table 2). In order to adequately assess the green content, four indicators were used:

- Indicator 1: the program contains more than $25 \%$ green content-Group I;

- Indicator 2: the program contains from $10 \%$ to $25 \%$ green content-Group II;

- Indicator 3: the program contains less than $10 \%$ and more than $0 \%$-Group III;

- Indicator 4: the program does not contain any green content-Group IV.

Table 2. Green content in curricula of bachelor and master programs-University of Novi Sad (UNS).

\begin{tabular}{|c|c|c|c|c|c|c|c|c|c|c|}
\hline \multirow{2}{*}{ Faculty/Criterion } & \multicolumn{2}{|c|}{ Number of Programs } & \multicolumn{2}{|c|}{ I-More than 25\% } & \multicolumn{2}{|c|}{ II-from $10 \%$ to $25 \%$} & \multicolumn{2}{|c|}{$\begin{array}{c}\text { III-Less than } 10 \% \text { and } \\
\text { More than } 0 \%\end{array}$} & \multicolumn{2}{|c|}{$\mathrm{IV}-0 \%$} \\
\hline & $\begin{array}{l}\text { Bachelor } \\
\text { (B) }\end{array}$ & Master (M) & B & $\mathbf{M}$ & B & $\mathbf{M}$ & B & $\mathbf{M}$ & B & $\mathbf{M}$ \\
\hline $\begin{array}{l}\text { Faculty of Technical } \\
\text { Sciences }\end{array}$ & 28 & 34 & 2 & 1 & 1 & 3 & 11 & 8 & 14 & 22 \\
\hline Faculty of Philosophy & 20 & 22 & 0 & 0 & 0 & 0 & 2 & 0 & 18 & 22 \\
\hline Faculty of Agriculture & 13 & 15 & 1 & 0 & 0 & 11 & 12 & 4 & 0 & 0 \\
\hline Faculty of Law & 2 & 4 & 0 & 0 & 0 & 0 & 0 & 0 & 2 & 4 \\
\hline Faculty of Sciences & 16 & 17 & 3 & 2 & 1 & 1 & 8 & 9 & 4 & 5 \\
\hline Faculty of Economics & 8 & 8 & 0 & 0 & 0 & 0 & 2 & 0 & 6 & 8 \\
\hline Faculty of Technology & 5 & 6 & 0 & 2 & 1 & 0 & 4 & 2 & 0 & 2 \\
\hline Academy of Arts & 14 & 15 & 0 & 0 & 0 & 0 & 0 & 0 & 14 & 15 \\
\hline Faculty of Medicine & 3 & 3 & 0 & 0 & 0 & 0 & 0 & 0 & 3 & 3 \\
\hline $\begin{array}{l}\text { Faculty of Civil } \\
\text { Engineering }\end{array}$ & 2 & 1 & 0 & 0 & 0 & 0 & 2 & 1 & 0 & 0 \\
\hline $\begin{array}{c}\text { Faculty of Spot Physical } \\
\text { Education }\end{array}$ & 1 & 1 & 0 & 0 & 0 & 0 & 0 & 0 & 1 & 1 \\
\hline Faculty of Education & 4 & 4 & 0 & 0 & 0 & 0 & 2 & 1 & 2 & 3 \\
\hline $\begin{array}{l}\text { Technical Faculty } \\
\text { „Mihajlo Pupin“ }\end{array}$ & 9 & 6 & 1 & 0 & 0 & 0 & 4 & 1 & 4 & 5 \\
\hline Teacher Training Faculty & 2 & 2 & 0 & 0 & 0 & 0 & 2 & 2 & 0 & 0 \\
\hline Total & 127 & 138 & $7(6 \%)$ & $5(4 \%)$ & $3(2 \%)$ & $15(11 \%)$ & $49(39 \%)$ & $28(20 \%)$ & $68(53 \%)$ & $90(65 \%)$ \\
\hline Total $(B+M)$ & \multicolumn{2}{|c|}{265} & \multicolumn{2}{|c|}{$12(4 \%)$} & \multicolumn{2}{|c|}{$18(7 \%)$} & \multicolumn{2}{|c|}{$77(29 \%)$} & \multicolumn{2}{|c|}{$158(60 \%)$} \\
\hline
\end{tabular}

Source: Authors.

In further analyses, all faculties were divided into five categories: Technical and Technological Sciences; Social Sciences and Humanities; Natural and Mathematical Sciences; Medical Sciences; and Art. The research was supplemented by a comparative analysis of the assessment of green content at the University of Novi Sad (UNS) and the University of Gothenburg (UGT) (Table 3) using two indicators:

- Indicator 1: the program contains more than $0 \%$ green content;

- Indicator 2: the program does not contain any green content.

This analysis examined whether there was a statistically significant difference in "green content" between the University of Novi Sad and the University of Gothenburg. An independent sample t-test was used to analyze the collected data. In order to illustrate a clear view to the readers, the authors have provided a flowchart of the adopted methodology (Figure 1). 
Table 3. Green content in curriculum-UNS vs. University of Gothenburg (UGT).

\begin{tabular}{|c|c|c|c|c|c|c|}
\hline Field/Faculty & Faculty UNS & $\begin{array}{l}\text { UNS-More } \\
\text { than } 0 \%\end{array}$ & UNS- $0 \%$ & Faculty UGT & $\begin{array}{l}\text { UGT-More } \\
\text { than } 0 \%\end{array}$ & UGT- $\%$ \\
\hline \multirow{5}{*}{$\begin{array}{l}\text { Technical and } \\
\text { Technological } \\
\text { Sciences }\end{array}$} & $\begin{array}{l}\text { Faculty of Technical } \\
\text { Sciences }\end{array}$ & $42 \%$ & $58 \%$ & \multirow{5}{*}{ IT Faculty } & \multirow{5}{*}{$0 \%$} & \multirow{5}{*}{$100 \%$} \\
\hline & Faculty of Technology & $82 \%$ & $18 \%$ & & & \\
\hline & Faculty of Agriculture & $100 \%$ & $0 \%$ & & & \\
\hline & $\begin{array}{l}\text { Faculty of Civil } \\
\text { Engineering }\end{array}$ & $100 \%$ & $0 \%$ & & & \\
\hline & $\begin{array}{l}\text { Technical Faculty } \\
\text { „Mihajlo Pupin“ }\end{array}$ & $40 \%$ & $60 \%$ & & & \\
\hline \multirow{5}{*}{$\begin{array}{l}\text { Social Sciences } \\
\text { and Humanities }\end{array}$} & Faculty of Philosophy & $5 \%$ & $95 \%$ & $\begin{array}{l}\text { Faculty of Social } \\
\text { Sciences }\end{array}$ & $23 \%$ & $77 \%$ \\
\hline & $\begin{array}{l}\text { Faculty of Law } \\
\text { Faculty of Economics }\end{array}$ & $\begin{array}{c}0 \% \\
12.5 \%\end{array}$ & $\begin{array}{l}100 \% \\
87.5 \%\end{array}$ & $\begin{array}{l}\text { School of Business, } \\
\text { Economics and Law }\end{array}$ & $27 \%$ & $73 \%$ \\
\hline & $\begin{array}{l}\text { Faculty of Spot } \\
\text { Physical Education }\end{array}$ & $0 \%$ & $100 \%$ & \multirow{3}{*}{ Faculty of Education } & \multirow{3}{*}{$0 \%$} & \multirow{3}{*}{$100 \%$} \\
\hline & Faculty of Education & $37.5 \%$ & $62.5 \%$ & & & \\
\hline & $\begin{array}{c}\text { Teacher Training } \\
\text { Faculty }\end{array}$ & $100 \%$ & $0 \%$ & & & \\
\hline $\begin{array}{l}\text { Natural and } \\
\text { Mathematical } \\
\text { Sciences }\end{array}$ & Faculty of Sciences & $73 \%$ & $27 \%$ & Faculty of Science & $79 \%$ & $21 \%$ \\
\hline Medical Sciences & Faculty of Medicine & $0 \%$ & $100 \%$ & $\begin{array}{c}\text { Sahlgrenska Academy } \\
\text { (Medicine, } \\
\text { Odontology and } \\
\text { Health and Care } \\
\text { Sciences) }\end{array}$ & $77 \%$ & $23 \%$ \\
\hline \multirow[t]{2}{*}{ Art } & \multirow[t]{2}{*}{ Academy of Arts } & \multirow[t]{2}{*}{$0 \%$} & \multirow[t]{2}{*}{$100 \%$} & $\begin{array}{l}\text { Faculty of Art } \\
\text { Faculty of Fine }\end{array}$ & $42 \%$ & $58 \%$ \\
\hline & & & & $\begin{array}{l}\text { Applied and } \\
\text { Performing Arts }\end{array}$ & $10 \%$ & $90 \%$ \\
\hline No. of programs & & 265 & & & 133 & \\
\hline
\end{tabular}

Source: Authors, [35].

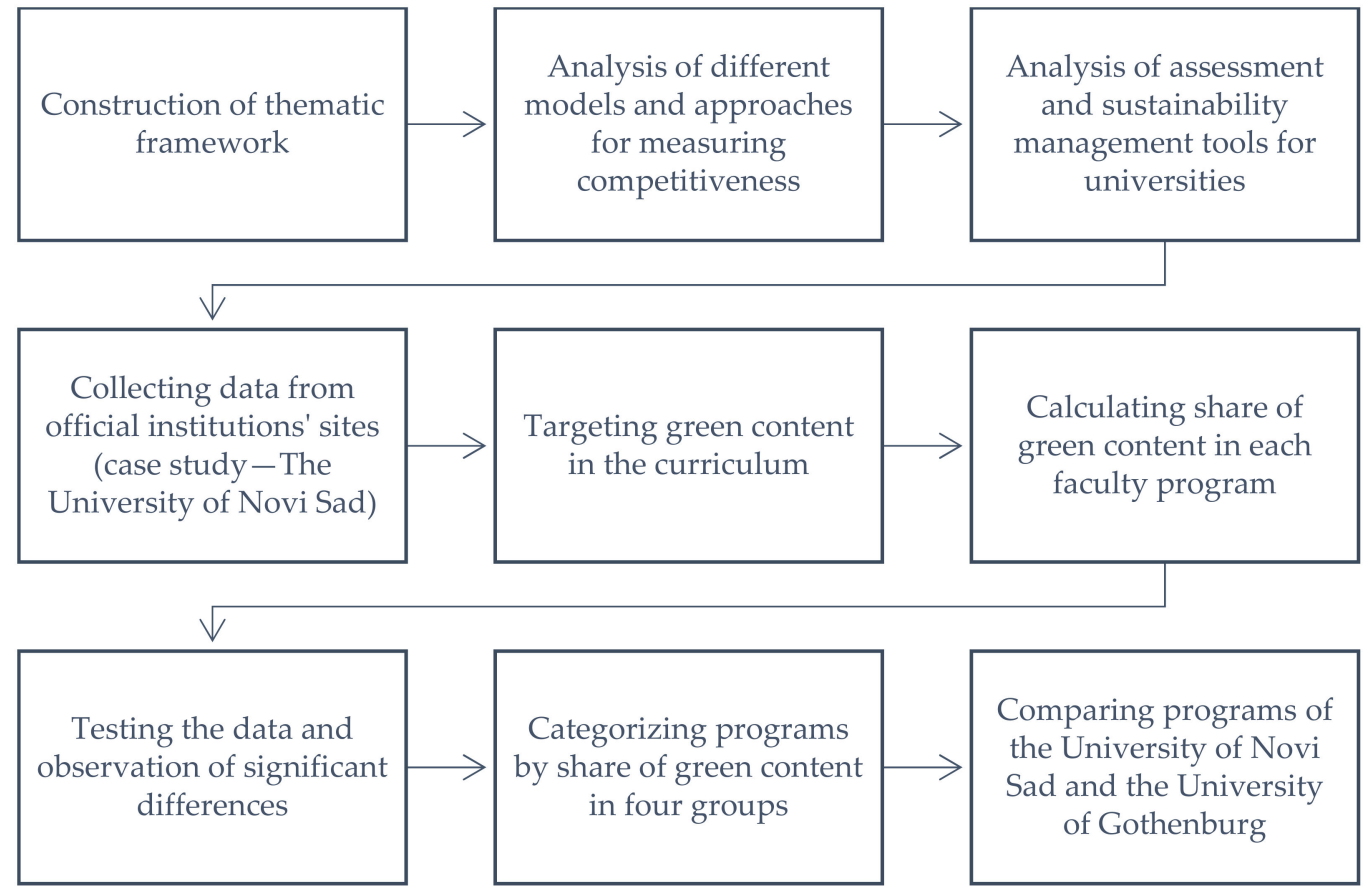

Figure 1. Flowchart of the adopted methodology. 


\subsection{Results}

Table 2 presents the assessment of green content in the curricula of bachelor and master programs at the University of Novi Sad in 2020. Table 3 shows the comparison of the share of green content in study programs at the University of Gothenburg and the University of Novi Sad according to individual faculties and scientific fields.

The significance of the applied test is $p<0.0005$, which is less than the marginal level of significance $(p<0.05)$, on the basis of which it could be concluded that there is a statistically significant difference in the context of "green content" in bachelor studies at the University of Novi Sad. The most common are bachelor studies that do not have "green content" at all with $53 \%$ and studies with "green content" from $0 \%$ to $10 \%$ with $39 \%$, and there is a large deviation from bachelor studies containing over $25 \%$ "green content" with $6 \%$ as well as studies containing $10 \%$ to $25 \%$ with $2 \%$.

The significance of the applied test is $p<0.0005$, which is less than the marginal level of significance $(p<0.05)$, based on which it could be concluded that there is a statistically significant difference in the context of "green content" in the master studies of the University of Novi Sad. The most common are master studies that do not have "green content" at all with $65 \%$ and significantly deviate from master studies with "green content" from $0 \%$ to $10 \%$ at $20 \%$ followed by studies containing from $10 \%$ to $25 \%$ with $11 \%$ as well as studies containing over $25 \%$ "green content" at $4 \%$.

Further analysis examined whether there was a statistically significant difference in "green content" between the University of Novi Sad and the University of Gothenburg. An independent sample t-test was used to analyze the collected data. The significance of the t-test is $p=0.564$, which is higher than the marginal level of significance $(p<0.05)$, based on which it could be concluded that there is no statistically significant difference in the amount of "green content" between the compared universities.

\section{Discussion}

Now, more than ever before, the society in which we live needs to change the value system of its inhabitants in the direction of sustainable development and environmental protection. The state, the local community, the public sector, companies, and also the higher education sector have a particularly important role in such efforts. By including so-called environmental education in their programs, universities around the world are building people's awareness of the importance of combatting the negative effects of man on nature. Many studies have confirmed the close connection between environmental knowledge and pro-environmental attitudes [84]. For this reason, more and more programs are adopting the principle of learning communities for action and measure different impact indicators [85]. Furthermore, universities have become creators of strategies and action plans in the fight against climate change and pollution, advocating for increasing the use of renewable energy sources, improving energy efficiency, and much more. Researchers [86] emphasize the importance of integrating ecological objectives in universities, such as different key ecological considerations. Hence, the achieved conditions of biodiversity conservation, habitat preservation, and ecosystem integrity must be analyzed and fostered in the way of integrating green priorities into the university. Such activities of universities are recognized in society, and today, they affect their competitiveness, i.e., the quality assessment of higher education institutions. For this reason, universities today need to take advantage of the new age and apply modern technological solutions to preserve the environment for future generations. Furthermore, the questions of the sustainability of higher education systems, sustainable universities, and green campuses, especially regarding the analyses of global approaches to sustainability through learning and education, barriers to innovation and sustainability at universities, and students' perceptions of sustainability from green and non-green universities, have been the focus of both academic and professional communities, while establishing the sound conceptual and methodological framework and thus enabling an effective and efficient process of optimal decision making [87-90]. 
It can be concluded that there is a large volume of scientific literature dedicated to this topic, which indicates its importance. However, what is currently lacking is a clearer view of the situation in higher education when it comes to the share of green content in the curricula of university study programs. Table 1 presents the results which showed all the analyzed methodologies of various organizations as separate indicators for evaluation of the green content in the curriculum. Through these examples, it is possible to see that many prominent international organizations such as UNESCO and the European Commission have become involved in the issue of qualifying green content in study programs at universities as they consider these activities as being greatly important for their competitiveness. Furthermore, systems for detailed monitoring of various individual university measures have been established, such as The Sustainability Tracking, Assessment, and Rating System (STARS) or the EU Eco-Management and Audit Scheme (EMAS), which have managed to involve a large number of universities around the world, as shown by the interest of higher education institutions themselves in collecting clear information about green content in their program curricula and, thus, their sustainable competitiveness. In the report [91], it is stressed that green and creative sharing, social, alternative economies will become very popular in 30 years.

The research further included the assessment of green content at the University of Novi Sad and showed that most of the studied faculties offer undergraduate study programs that either have no share or have content with up to a 10\% share of green material (Table 2). Regarding master's academic studies, we can notice a similar situation, although some institutions such as the Faculty of Agriculture show better results because at this level of study, they offer programs that mostly contain $10 \%$ to $25 \%$ green content. Based on the conducted analysis, we can determine that bachelor's and master's studies that do not contain "green content" are the most common at the University of Novi Sad. The necessity of further eco-labeling of bachelor's and master's studies is required because it is a good tool for promotion of green study content. A worrying figure shows that as much as $60 \%$ (2019/20) of UNS and 55.7\% (2010/11) of UGT programs [35] do not have any green content. This situation cannot be considered satisfactory, so it is certainly necessary to examine in more detail those programs where such content is completely absent. Comparing the results obtained at UNS (2019/20) and UGT (2010/11), it was found that the situation regarding the inclusion of green content in programs is quite similar, except when it comes to the field of medical sciences and the artistic field, where UGT shows better results. On the other hand, UNS is much better in the technical field (Table 3). However, since applying eco-labeling, UGT has significantly reduced the percentage of programs without green content, from $69.3 \%(2006 / 07)$ to $55.7 \%$ (2010/11) [35]. The conducted research shows the confirmation of the main hypothesis of the paper, which reads: Assessment of green content in the curriculum is essential to achieve sustainable competitiveness of university campuses. This situation could be improved by the use of eco-labels that would help with easier identification of study content dedicated to sustainable development, which is an example of good practice at UGT. As a result of classification, the study programs would be given certain eco-labels created by the university, the significance of which is described in detail in the paper. In this way, faculties that have more programs (at all levels of studies), which include contents aimed at sustainable development, could count on the positive effects ensured from promotion through green marketing or eco-labeling. Furthermore, faculties would become more aware of the scope of material dedicated to sustainable development in individual programs, and in this way, they could follow trends over the years as well as assess their effects more accurately. In this way, it is possible to assign appropriate eco-labels to study programs that would help with easier identification of those contents that, in a certain share, contribute to sustainable development promotion. Through eco-labels, they would become more recognizable and it would be easier to follow them, additionally subsidize them, or support them in other ways. Furthermore, this eco-labeling methodology could be easily applied to other universities in the country and 
the region and thus have an even more positive impact on today's stakeholders in higher education, as well as on the wider community.

\section{Conclusions}

In recent decades, we have witnessed the collapse of the environment and the unsustainable depletion of natural resources. Numerous environmental crises have led decision-makers around the world to set ambitious goals that should ensure a greater degree of sustainable development of our planet. As awareness of the increasing need to reduce the consumption of natural resources grows, there is great pressure on scientific and research institutions to increase the percentage of products that will guarantee sustainability in production. For this reason, today, there is almost no area of human action that should not be corrected in some way or at least monitored from the angle of its effect on the environment. Therefore, there is a need for education and development of young people who will be the bearers of a new wave of eco-innovations. For this reason, the world's leading universities have launched progressing work on green curricula in most areas. For universities in developing countries, this requirement is a little harder to achieve, but far from not being achievable. In the case of developing countries, where the University of Novi Sad is located, more incentives from the state and more coordinated action by all actors (society, industry, local government) are needed to launch more green programs. Due to all the above, the field of studying the concept of competitiveness and its measurement shifts towards indicators that can quantitatively or qualitatively describe some of the activities important for ecology and the environment.

Universities, as traditional bearers of change, have an obligation to educate new generations of professionals by offering them modified content of study programs. The main evidence for initiating concern for environmental protection is the emergence and penetration of green content at the University of Novi Sad. This comparative case study analysis addresses the impact of the environmental orientation of university curricula towards more green content. It considers the final outcomes in relation to green environmental orientation, green marketing strategy and eco-labeling strategy as attractions of future carriers of R\&D in eco-innovations, green startups, green entrepreneurs, etc. As most universities are willing to discover, ways to achieve green orientation is an area of growing interest for society, state and industry.

Higher education institutions around the world are looking for opportunities that will lead them to a greater degree of including green content in their study programs. In this way, they fight to achieve a better image and influence on society, as well as overall competitiveness. In a time when we are surrounded by huge amounts of information that we receive every day, the need to simplify and summarize them is becoming more pronounced. Based on the research, an insufficient share of green content can be noticed at both analyzed universities. However, with the use of eco-labels over the years, a positive trend in the growth of the number of programs with green content has been observed. That is why it is important to use adequate tools for assessing green content in the curriculum and also to promote it in the right way. Eco-labels have such properties, and that is why their use and number are growing day by day.

The paper presents the importance and possibilities of their use in marking the share of green contents in study programs. The presented research speaks in favor of their importance for raising environmental awareness in universities, which would consequently lead to an increase in their overall competitiveness in the higher education market. The weaknesses of the conducted research, that is, analyses, is in understanding the existing gap while performing a full-scale analysis of broader factors that affect university competitiveness, both short and long term. Namely, the limitation of the research, particularly regarding acquired knowledge and information on important aspects of the subject matter, is that it is not being generalized and that it should be followed by further research.

The paper provides many opportunities for further research such as expanding research to other universities in the country and the region, exploring opportunities for 
eco-labeling of conferences, projects, doctoral dissertations, etc., the impact of the potential application of eco-labels on students and other university partners and many more. It is very important to underline that incorporating sustainability into curricula is not only for the purpose of advancement in competitiveness but also for the impact on the qualification of graduates and on changing behaviors of graduates. As mentioned and presented in previous research in literature, eco-labeling made a significant change in more sustainable management of the campuses themselves as well as a contribution to more eco-consciousness of local society. Further research will also focus on the impact of eco-labeling of green campuses and green curricula on the behavior of students and graduates differentiating in groups, for example, measuring eco-awareness of students who study or graduate on studies and universities with green content and exploration of behavior and awareness of other groups-students and graduates on studies and programs without green content. Introducing the impact indicators of changed behavior, we could expand and substantiate the impact of eco-labeling and including more green content in the curricula of different courses. Investing in the green content in curricula is investing in the future not only for one country, but worldwide.

Author Contributions: Conceptualization, A.O. and J.J.; methodology, V.Đ.; investigation, A.O.; resources, S.V.; writing — original draft preparation, A.O. and A.A.P.; writing — review and editing, S.V.; visualization, V.Đ.; supervision, J.J. and A.A.P. All authors have read and agreed to the published version of the manuscript.

Funding: This research (paper) was supported by the Ministry of Education, Science and Technological Development through the project no. 451-03-68/2020-14/200156: “Innovative scientific and artistic research from the FTN (activity) domain" and the Institute of Field and Vegetable Crops, Realization and financing contract for research work in 2020, Record number: 451-03-68/2020-14/200032.

Institutional Review Board Statement: Not applicable.

Informed Consent Statement: Not applicable.

Data Availability Statement: Data available in a publicly accessible repository that does not issue DOIs. Publicly available datasets were analyzed in this study. This data can be found here: [https://www.uns.ac.rs/index.php/en/].

Conflicts of Interest: The authors declare no conflict of interest. The funders had no role in the design of the study; in the collection, analyses, or interpretation of data; in the writing of the manuscript, or in the decision to publish the results.

\section{References}

1. Brundtland, G.H.; Khalid, M.; Agnelli, S.; Al-Athel, S.; Chidzero, B. Our Common Future; Oxford University Press: New York, NY, USA, 1987; Volume 8.

2. Bruckmeier, K. The Policy Context of the Sustainability Discourse. In Economics and Sustainability; Palgrave Macmillan: Cham, Switzerland, 2020; pp. 3-37. [CrossRef]

3. United Nations. Transforming Our World: The 2030 Agenda for Sustainable Development. In Proceedings of the General Assembley 70 Session, New York, NY, USA, 15 September 2015.

4. Chakraborty, D. Role of Eco-Efficiency in Evaluating Environmental Performance and in Accomplishing Sustainable Development Goals Case Study of ITC Ltd. Manag. Account. J. 2020, 55, 95-101.

5. Marrone, P.; Orsini, F.; Asdrubali, F.; Guattari, C. Environmental performance of universities: Proposal for implementing campus urban morphology as an evaluation parameter in Green Metric. Sustain. Cities Soc. 2018, 42, 226-239. [CrossRef]

6. Langevin, J.; Gurian, P.L.; Wen, J. Reducing energy consumption in low income public housing: Interviewing residents about energy behaviors. Appl. Energy 2013, 102, 1358-1370. [CrossRef]

7. UNESCO. Education for Sustainable Development Unit (ESD). Available online: http:/ /www.unescobkk.org/fr/education/esdunit/definition-of-esd/ (accessed on 13 April 2020).

8. Geng, Y.; Liu, K.; Xue, B.; Fujita, T. Creating a "green university" in China: A case of Shenyang University. J. Clean. Prod. 2013, 61, 13-19. [CrossRef]

9. Lozano, R.; Lukman, R.; Lozano, F.J.; Huisingh, D.; Lambrechts, W. Declarations for sustainability in higher education: Becoming better leaders, through addressing the university system. J. Clean. Prod. 2013, 48, 10-19. [CrossRef]

10. Xiong, H.; Fu, D.; Duan, C.; Chang, E.L.; Yang, X.; Wang, R. Current status of green curriculum in higher education of Mainland China. J. Clean. Prod. 2013, 61, 100-105. [CrossRef] 
11. Costanza, R.; Hart, M.; Kubiszewski, I.; Talberth, J. Moving beyond GDP to measure well-being and happiness. Solutions 2014, 5,91-97.

12. European Commission. Enterprise DG. In European Competitiveness, Report 2000: Working Document of the Services of the European Commission; Office for Official Publications of the European Communities: Luxembourg, 2000.

13. Chikan, A. National and firm competitiveness: A general research model. Compet. Rev. Int. Bus. J. 2008, 18, 20-28. [CrossRef]

14. Katić, A.; Ćosić, I.; Anđelić, G.; Raletić, S. Review of competitiveness indices that use knowledge as a criterion. Acta Polytech. Hung. 2012, 9, 25-45.

15. Okanović, A.; Jokanović, B.; Kisin, J. Sustainable Business for Companies in a Global Environment. Ecologica 2018, 25, 489-494.

16. WEF. The Global Competitiveness Report 2014-2015; World Economic Forum: Geneva, Switzerland, 2014.

17. Doyle, E.; Perez-Alaniz, M. From the concept to the measurement of sustainable competitiveness: Social and environmental aspects. Entrep. Bus. Econ. Rev. 2017, 5, 35-59. [CrossRef]

18. Möbius, P.; Althammer, W. Sustainable competitiveness: A spatial econometric analysis of European regions. J. Environ. Plan. Manag. 2020, 63, 453-480. [CrossRef]

19. Despotovic, D.; Cvetanovic, S.; Nedic, V.; Despotovic, M. Economic, social and environmental dimension of sustainable competitiveness of European countries. J. Environ. Plan. Manag. 2016, 59, 1656-1678. [CrossRef]

20. Qazi, W.; Qureshi, J.A.; Raza, S.A.; Khan, K.A.; Qureshi, M.A. Impact of personality traits and university green entrepreneurial support on students' green entrepreneurial intentions: The moderating role of environmental values. J. Appl. Res. High. Educ. 2020. ahead-of-print. [CrossRef]

21. Fichter, K.; Tiemann, I. Factors influencing university support for sustainable entrepreneurship: Insights from explorative case studies. J. Clean. Prod. 2018, 175, 512-524. [CrossRef]

22. Theodoraki, C.; Messeghem, K.; Rice, M.P. A social capital approach to the development of sustainable entrepreneurial ecosystems: An explorative study. Small Bus. Econ. 2018, 51, 153-170. [CrossRef]

23. Singh, R.K.; Murty, H.R.; Gupta, S.K.; Dikshit, A.K. An overview of sustainability assessment methodologies. Ecol. Indic. 2009, 9, 189-212. [CrossRef]

24. Krajnc, D.; Glavič, P. A model for integrated assessment of sustainable development. Resour. Conserv. Recycl. 2005, 43, 189-208. [CrossRef]

25. Okanović, A.; Ješić, J.; Vukadinović, S. An overview of sustainable competitiveness composite indices. In Proceedings of the 1st Virtual International Conference Path to a Knowledge Society-Managing Risks and Innovation; Research and Development Center "IRC ALFATEC": Niš, Serbia; Complex System Research Centre: Niš, Serbia, 2019; pp. 119-124. ISBN 978-86-80616-05-6.

26. Popescu, G.H.; Sima, V.; Nica, E.; Gheorghe, I.G. Measuring sustainable competitiveness in contemporary economies-Insights from European economy. Sustainability 2017, 9, 1230. [CrossRef]

27. Schwab, K. The Fourth Industrial Revolution; Currency: Redfern, Australia, 2017.

28. Dehghanmongabadi, A.; Hoşkara, Ş. Challenges of promoting sustainable mobility on university campuses: The case of Eastern Mediterranean University. Sustainability 2018, 10, 4842. [CrossRef]

29. Garbie, I.H. Incorporating sustainability/sustainable development concepts in teaching industrial systems design courses. Procedia Manuf. 2017, 8, 417-423. [CrossRef]

30. Gomez, C.P.; Ng, Y.Y. Development of a progressive green university campus maturity assessment tool and framework for Malaysian universities. MATEC Web Conf. 2019, 266, 01018. [CrossRef]

31. León-Fernández, Y.; Gomera, A.; Antúnez, M.; Martínez-Escrich, B.; Villamandos, F.; Vaquero, M. Enhancing environmental management in universities through participation: The case of the University of Córdoba. J. Clean. Prod. 2018, 172, $4328-4337$. [CrossRef]

32. Azapagic, S.P.; Shallcross, D. How much do engineering students know about sustainable development? The findings of an international survey and possible implications for the engineering curriculum. Eur. J. Eng. Educ. 2005, 30, 1-19. [CrossRef]

33. Anityasarl, M. Inserting the Concepts of Sustainable Manufacturing into Industrial Engineering Curriculum-A Framework of Thoughts; Sepuluh Nopember Institute of Technology: Surabaya, Indonesia, 2011.

34. Capdevila, I.; Bruno, J.; Jofre, L. Curriculum greening and environmental research co-ordination at the Technical University of Catalonia Barcelona. J. Clean. Prod. 2002, 10, 25-31. [CrossRef]

35. Lozano, R.; Lozano, F.J.; Mulder, K.; Huisingh, D.; Waas, T. Advancing higher education for sustainable development: International insights and critical reflections. J. Clean. Prod. 2013, 48, 3-9. [CrossRef]

36. Leal Filho, W.; Raath, S.; Lazzarini, B.; Vargas, V.R.; de Souza, L.; Anholon, R.; Quelhas, O.L.G.; Haddad, R.; Klavins, M.; Orlovic, V.L. The role of transformation in learning and education for sustainability. J. Clean. Prod. 2018, 199, 286-295. [CrossRef]

37. Perello-Marín, M.R.; Ribes-Giner, G.; Pantoja Díaz, O. Enhancing education for sustainable development in environmental university programmes: A co-creation approach. Sustainability 2018, 10, 158. [CrossRef]

38. Pappas, E.; Pierrakos, O.; Nagel, R. Using Bloom's Taxonomy to teach sustainability in multiple contexts. J. Clean. Prod. 2013, 48, 54-64. [CrossRef]

39. Too, L.; Bajracharya, B. Sustainable campus: Engaging the community in sustainability. Int. J. Sustain. High Educ. 2015, 16, 57-71. [CrossRef]

40. Sonetti, G.; Lombardi, P.; Chelleri, L. True green and sustainable university campuses? Toward a clusters approach. Sustainability 2016, 8, 83. [CrossRef] 
41. Sterling, S. The sustainable university: Challenge and response. In The Sustainable University: Progress and Prospects; Sterling, S., Maxey, L., Luna, H., Eds.; Routledge: London, UK, 2013.

42. Connect for Climate. Past Competitions. Available online: https://www.connect4climate.org/article/connect4climate-pastcompetitions (accessed on 23 December 2020).

43. Hokkaido University. Available online: https://www.osc.hokudai.ac.jp/en/what-sc (accessed on 13 April 2020).

44. Brkanlić, S.; Okanović, A.; Raletić-Jotanović, S. The ecological aspect of the impact of service environment on the image of higher education institutions. Ecology 2016, 84, 888-893.

45. McIntosh, M.; Gaalswyk, K.; Keniry, J.; Eagan, D. Campus Environment 2008: A National Report Card on Sustainability in Higher Education; National Wildlife Federation: Reston, VA, USA, 2008.

46. Kamal, A.S.M.; Asmuss, M. Benchmarking tools for assessing and tracking sustainability in higher educational institutions: Identifying an effective tool for the University of Saskatchewan. Int. J. Sustain. High. Educ. 2013, 14, 449-465.

47. Urbanski, M.; Leal Filho, W. Measuring sustainability at universities by means of the Sustainability Tracking, Assessment and Rating System (STARS): Early findings from STARS data. Environ. Dev. Sustain. 2015, 17, 209-220. [CrossRef]

48. McIntosh, M.; Cacciola, K.; Clermont, S.; Keniry, J. State of the Campus Environment: A National Report Card on Environmental Performance and Sustainability in Higher Education; National Wildlife Federation: Reston, VA, USA, 2001; pp. 78-97.

49. Olszak, E. Composite indicators for a sustainable campus-Design rationale and methodology: The case of the Catholic Institute of Lille. Ecol. Indic. 2012, 23, 573-577. [CrossRef]

50. Khan, E.A.; Royhan, P.; Rahman, M.A.; Rahman, M.M.; Mostafa, A. The Impact of Enviropreneurial Orientation on Small Firms Business Performance: The Mediation of Green Marketing Mix and Eco-Labeling Strategies. Sustainability 2020, 12, 221. [CrossRef]

51. Testa, F.; Iraldo, F.; Vaccari, A.; Ferrari, E. Why eco-labels can be effective marketing tools: Evidence from a study on Italian consumers. Bus. Strategy Environ. 2013. [CrossRef]

52. Thøgersen, J.; Haugaard, P.; Olesen, A. Consumer responses to ecolabels. Eur. J. Mark. 2013, 44, 1787-1810. [CrossRef]

53. Van Amstel, M.; Driessen, P.; Glasbergen, P. Eco-labeling and information asymmetry: A comparison of five eco-labels in the Netherlands. J. Clean. Prod. 2008, 16, 263-276. [CrossRef]

54. Rex, E.; Baumann, H. Beyond ecolabels: What green marketing can learn from conventional marketing. J. Clean. Prod. 2007, 15, 567-576. [CrossRef]

55. Sitarz, D. Agenda 21: The Earth Summit Strategy to Save Our Planet; EarthPress: Boulder, CO, USA, 1994.

56. Teisl, M.F.; Rubin, J.; Noblet, C.L. Non-dirty dancing? Interactions between eco-labels and consumers. J. Econ. Psychol. 2008, 29, 140-159. [CrossRef]

57. Boman, J.; Andersson, U.P. Eco-labelling of courses and programs at University of Gothenburg. J. Clean. Prod. 2013, 48, 48-53. [CrossRef]

58. Hickman, D.C.; Meyer, A.G. Does eco-labeling of services matter? Evidence from higher education. BE J. Econ. Anal. Policy 2016, 16, 1-18. [CrossRef]

59. Bullock, G.; Wilder, N. The comprehensiveness of competing higher education sustainability assessments. Int. J. Sustain. High. Educ. 2016, 17, 282-304. [CrossRef]

60. World University Rankings. Available online: https:/ /www.timeshighereducation.com/ (accessed on 23 December 2020).

61. International University Sports Federation. Available online: https://www.fisu.net/healthy-campus/ (accessed on 23 December 2020).

62. Certified B Corporations. Available online: https:/ / bcorporation.net/welcome-sdg-action-manager/ (accessed on 23 December 2020).

63. Principles of Responsible Management Education. Available online: https:/ / www.unprme.org/\# (accessed on 23 December 2020).

64. Eco-Schools. Available online: https://www.ecoschools.global/ (accessed on 23 December 2020).

65. Shriberg, M. Institutional assessment tools for sustainability in higher education: Strengths, weaknesses, and implications for practice and theory. Int. J. Sustain. High. Educ. 2002, 3, 254-270. [CrossRef]

66. UNESCO. The Sustainable Campus Network. Available online: https://en.unesco.org/greencitizens/stories/sustainablecampus-network (accessed on 13 April 2020).

67. ISCN. About ISCN. Available online: https://international-sustainable-campus-network.org/about-iscn/ (accessed on 13 April 2020).

68. Nanyang Technological University, Singapore (NTU Singapore). Ecocampus. Available online: https://ecocampus.ntu.edu.sg/ Pages/index.aspx (accessed on 25 April 2020).

69. STARS. About STARS. Available online: https://stars.aashe.org/ (accessed on 3 April 2020).

70. UIC-The Office of Sustainability. Climate Action Implementation Plan. Available online: http://sustainability.uic.edu/plans/ caip/ (accessed on 5 April 2020).

71. Tanaka, A.; Tabucanon, M. Transforming Higher Education and Creating Sustainable Societies; United Nations University Institute for the Advanced Study of Sustainability (UNU-IAS): Tokyo, Japan, 2014.

72. The ProSPER.Net. Disaster Resilience and Sustainable Development Education Network in Asia. Available online: https:// prospernet.ias.unu.edu/projects / past-projects / disaster-resilience-and-sustainable-development-education-network-in-asia (accessed on 5 April 2020).

73. People \& Planet's University League. How Sustainable is Your University? Available online: https://peopleandplanet.org/ university-league (accessed on 5 March 2020).

74. Newcastle University. Sustainable Campus. Available online: https://www.ncl.ac.uk/sustainable-campus/themes/carbon/ (accessed on 15 March 2020). 
75. Abeliotis, K. A review of EMAS in Greece: Is it effective? J. Clean. Prod. 2006, 14, 1644-1647. [CrossRef]

76. European Commission. Environment. Eco-Management and Audit Scheme. Available online: https://ec.europa.eu/ environment/emas/index_en.htm (accessed on 20 March 2020).

77. Gómez, F.U.; Saez-Navarrete, C.; Lioi, S.R.; Marzuca, V.I. Adaptable model for assessing sustainability in higher education. J. Clean. Prod. 2015, 107, 475-485. [CrossRef]

78. Green Metrics, World University Rankings. Available online: http:/ / greenmetric.ui.ac.id/ (accessed on 23 November 2020).

79. Clarke, A.; Kouri, R. Choosing an appropriate university or college environmental management system. J. Clean. Prod. 2009, 11, 971-984. [CrossRef]

80. The University of Gothenburg. About the University. Available online: https://www.gu.se/english/about_the_university (accessed on 16 March 2020).

81. Lagrell, E. Labelling of Courses. In Evaluation of Eco-Labelling of Courses and Programs at University of Gothenburg; Project in the Course Practical Environmental Studies; University of Gothenburg: Gothenburg, Sweden, 2008.

82. University of Novi Sad. About the University. Available online: http://www.uns.ac.rs/index.php/en/university/o-univerzitetue (accessed on 20 March 2020).

83. University of Novi Sad. Members. Available online: http://www.uns.ac.rs/index.php/c-clanice/fakulteti/18-clanice/281centar-za-odrzivi-razvoj-2 (accessed on 20 March 2020).

84. Zsóka, Á.; Szerényi, Z.M.; Széchy, A.; Kocsis, T. Greening due to environmental education? Environmental knowledge, attitudes, consumer behavior and everyday pro-environmental activities of Hungarian high school and university students. J. Clean. Prod. 2013, 48, 126-138. [CrossRef]

85. Varela-Losada, M.; Vega-Marcote, P.; Pérez-Rodríguez, U.; Álvarez-Lires, M. Going to action? A literature review on educational proposals in formal Environmental Education. Environ. Educ. Res. 2016, 22, 390-421. [CrossRef]

86. Orenstein, D.E.; Troupin, D.; Segal, E.; Holzer, J.M.; Hakima-Koniak, G. Integrating ecological objectives in university campus strategic and spatial planning: A case study. Int. J. Sustain. High. Educ. 2019, 20, 190-213. [CrossRef]

87. Salvioni, D.M.; Franzoni, S.; Cassano, R. Sustainability in the higher education system: An opportunity to improve quality and image. Sustainability 2017, 9, 914. [CrossRef]

88. Ávila, L.V.; Leal Filho, W.; Brandli, L.; Macgregor, C.J.; Molthan-Hill, P.; Özuyar, P.G.; Moreira, R.M. Barriers to innovation and sustainability at universities around the world. J. Clean. Prod. 2017, 164, 1268-1278. [CrossRef]

89. Dagiliūtè, R.; Liobikienè, G.; Minelgaitè, A. Sustainability at universities: Students' perceptions from Green and Non-Green universities. J. Clean. Prod. 2018, 181, 473-482. [CrossRef]

90. Momani, K.M.; Nour, A.I.; Jamaludin, N. Sustainable Universities and Green Campuses. In Global Approaches to Sustainability through Learning and Education; Al-Sartawi, A.M., Hussainey, K., Hannoon, A., Hamdan, A., Eds.; IGI Global: Hershey, PA, USA, 2020; pp. 17-27. [CrossRef]

91. Barbosa, C.E.; Lima, Y.; Souza, J.; Santos, E.; Costa, L.; Carmo, A.; Kritz, J.; Almeida, D.; Kleinpaul, P.; Augusto, L. Working in 2050: A View of How Changes on the Work Will Affect Society. 2017. Available online: https://www.researchgate.net/publication/33 0857673_Working_in_2050_A_view_of_how_changes_on_the_work_will_affect_society (accessed on 15 July 2020). 